УДК: 7.046 .3

ББК: 85.14

A43

DOI: $10.18688 / \mathrm{aa} 200-1-3$

G. Perini Folesani

\title{
Borderline Iconographies: The Limits of Visual Communication in Conveying Christian Dogmas in Early Modern Europe
}

The main difference between Andrei Rublev's Old Testament Trinity in the Tretyakov Gallery in Moscow [1, p. 94 and pl. 49; 105, pp. 242-244 and 270-271; 55, pp. 289-291, 385-386, n. $101 ; 12$, pp. $35-36$, fig. $11 ; 81$, pp. 66-69, 167, 179-188, figs. 93-102; 69; 43, p. 235, fig. 307; 74, pp. 167-168 and fig. 53; 86, pp. 392-395] and Ludovico Carracci's Abraham and the Three Angels in the Bologna Pinacoteca [8, pp. 268-269, n. 178; 34, p. CV] is not about style ${ }^{1}$. It is about meaning, which is why they have different titles. Both paintings stem from the very same passage in the Bible (Old Testament, Genesis, ch. XVIII, lines 1-8). Andrei Rublev's icon presents the three angels sitting at Abraham's table as a typological manifestation of the holy Trinity [43, pp. 234-236]. Most later icons make it explicit by adding the words "holy Trinity" above them in either Greek or Russian². Rublev's invention for the three angels obviously draws on earlier Byzantine and post-Byzantine prototypes, usually featuring Abraham and Sarah next to the angels, preparing and serving their meal ${ }^{3}$. In the mosaics in Santa Maria Maggiore, Rome (5 $5^{\text {th }}$ century: [74, p. 167 and fig. 52; 14, fig. 11 on p. 70]), in St Vitale, Ravenna ( $6^{\text {th }}$ century: [20, p. $42 ; 14$, fig. 18 on p. 80$\left.]\right)$ and, much later, in the Monreale cathedral, near Palermo $\left(12^{\text {th }}-13^{\text {th }}\right.$ centuries: $[49$, tav. 34$\left.]\right)$ the married couple features as co-protagonists or deuteragonists ${ }^{4}$. It is no coincidence if such icons are also known as The Hospitality of Abraham.

As Alpatov has already pointed out [3, pp. 222-226, esp. p. 222, followed by 106, pp. $212-$ 217], Rublev's invention eliminates all ancillary figures, concentrating on the three angels and

The two pictures are almost equivalent in size. Although Rublev's icon looks more imposing, it measures $141 \times 114 \mathrm{~cm}$, whereas Ludovico Carracci's picture is slightly larger, measuring $158 \times 131 \mathrm{~cm}$ [8, pp. 268-269, entry n. 178].

See also infra, p. 38.

A number of both Greek and Russian examples can be seen in [69, pp. 50-58, esp. figs. 59-60, 62-65]. For Greek examples see also [30, p. 41, pl. 29] (14 ${ }^{\text {th }}$ century) and [52, pp. 82-83, n. 15] (datable to 1176-1180: curiously enough Sarah is not present, only Abraham is in sight). See also a 1092 Greek miniature [14, fig. 10 on p. 115]. A splendid though highly damaged fresco by Theophanes the Greek (1378) can be seen in the Cathedral of the Transfiguration in Novgorod: see [2, p. 277 and fig. 62].

${ }_{4}$ In Santa Maria Maggiore Rome the ubiquitous presence of Abraham makes him the protagonist twice, first in adoration of the three "angels" and then while serving their meal. The same happens in the much later mosaics of this scene in the atrium of St. Mark's Venice (13 $3^{\text {th }}$ century: [9, pp. 110-111, fig. 41]) and in the Palatine Chapel in Palermo [103, pl. XXXVII]. 
reducing any topographical element, such as the oak-tree or Abraham's dwelling, to symbolic allusions ${ }^{5}$. His image is built according to a most rigorous geometrical scheme, whose powerful abstraction enhances both its beauty and its significance $[85$, p. 158; 104; 106, p. 213]. As an icon, it is not a mimetic representation - it is a visual statement of Truth, the revelation of an article of faith [70, pp. 23-49; 94, pp. 13-32; 76, passim; 85, pp. 79-105 and 125-129; 86, pp. $65-85 ; 101$, pp. $35-118]^{6}$, in this case the Trinitarian dogma combined with the assertion of the unity of God's message in the Old and the New Testament. It is so powerful an image as to become the pattern conveyed by podlinniki (e.g. [91, pp. 383-390]) for endless new icons known as "the Rublev's Trinity". As a classic in orthodox iconography, it sometimes slips

$5 \quad$ In fact this had already been done by some of his predecessors, albeit less gifted: see e.g. [69, figs. 59 and 65] and more specifically, the first border scene in the 1399 Archangel icon from the Archangel Cathedral in the Moscow Cathedral [81, p. 180, figs. 1 and 4; 53, p. 32 and fig. 51, where a later dating is suggested], or a Hospitality of Abraham in the very Sergiev Posad State Museum [80, fig. 103, p. 210]. On the lost, seminal icon of the Old Testament Trinity, originally placed in the nave of the church of St Sophia in Costantinople, as well as on its special significance, especially in opposition to nearby Islamic tenets of faith, see [6, p. 241]. $6 \quad$ For a history of the development of icons and their functions, see [28].

Numerous faithful copies of Rublev's icon exist (such as the one in [41, p. 6, n. and fig. 19]), often including variations in the colours of the garments, (e.g. [87, pp. 136-137, fig. 44; 58, p. 3, n. 8; 85, pp. 157 and $159 ; 43$, p. 236, fig. 309; 51, p. 10, fig. 6]), especially when painted by remarkable masters like Paissi or Nikita Pavlovets [80, p. 264, figs. 101-103; 51, pp. 15-16, fig. 12]. Variations may also occur in details of the setting (for instance changing the shape and furnishings of the table: [87, pp. 93 and 104-105, fig. 32], or else its surroundings: [100, pp. 153-154, n. and fig. 128 by the Godunov school]). Occasionally Abraham and Sarah serving the meal are reintroduced ([1, p. 84 and pl. 42a; 101, p. 112, fig. 37] (the central episode in the lowest row of scenes); or [94, p. 137, n. 54 and fig. 111; 45, n. 59], by the Yaroslavl school, where Abraham and Sarah and the three angels feature also in three different scenes in the background. (Chagall must have taken inspiration from such icons for the side scenes in his peculiar depictions of this subject-matter, for which see infra). This model spans over the centuries and can be traced down to the $17^{\text {th }}([100, p .157, n$. and fig. 142, same as 106, p. 223, fig. 120], by Simon Ushakov: according to Zibawi, he celebrates the divorce between tradition and art, as he resumes ancient models to interpret them in the style of Raphael), $18^{\text {th }}$ (e.g. [58, p. 78, n. 53]) and even $19^{\text {th }}$ and $20^{\text {th }}$ centuries [ 85, p. 161]. As an iconographic pattern, the Rublev model reaches out to Ukraine [58, p. 92, fig. 7], Serbia (e.g. [105, p. 340], mid-16 $6^{\text {th }}$ century), Bulgaria [100, fig. 45] and even the Mediterranean (for Greece, see [25, fig. 44]; a specimen is preserved in the Byzantine Museum, Athens: see also [52, p. 148, fig. 21], where the Panagiarion decorated possibly by Nikolaos Ritzos is said to follow a Paleologan model; a similar Panagiarion by the same artist is in [26, pp. 74-75, n. 15]; ibidem also an Old Testament Trinity in the Correr Museum, Venice attributed to Vittore, dating to the late $17^{\text {th }}$ century), usually losing much of its elegance, style and beauty. Several specimens of different ages can be found even in the churches of St Basil's Cathedral in Moscow: e.g. [88, pp. 26-27, 32]. This pattern is also reproduced in different media, such as embroideries (occasionally called tapestries or shrouds in English texts: [1, p. 129 and pl. 69a; 87, pp. 216-217, fig. 79]). It may even occur in visions of saints, like in the one of Venerable Macarius of Unzha [32, pp. 152-153, n. 26], whereas in the Vision of St Basil the Blessed by the Stroganov School at the Tretyakov Gallery [105, pl. 11: cf. 63, pp. 260-261, fig. n. 118] the Old Testament Trinity follows a different model. The Rublev pattern is occasionally detectable in composite icons such a $17^{\text {th }}$ - century one in the Andrei Rublev Museum, Moscow from the Veliky Ustyung province showing the Harrowing of Hell, Feasts and selected saints, where it features on the top left hand corner [67, pp. 36-37 or 63, pp. 258-259, n. 117], or in an $18^{\text {th }}$-century Deesis with the Harrowing of Hell and the Holy Trinity possibly from Kargopol [67, pp. 89 and 102, fig. 46]. In fact, the Holy Trinity is included in most Feast icons, where it generally follows the Rublev model, thus ensuring its ubiquitous presence throughout Russia: see e.g. [79, I, pp. 98-99, n. 31; II, pp. 386-387, n. 174 and pp. 558-559, n. 259] (together with a New Testament Trinity) and [63, pp. 268-269, n. 122]. It is also detectable in border stories of larger icons, like in the 1560 icon of Archangel Michael in Sviyazhsk [87, pp. 46-47, n. 8: cf. above, note 5] or in the late Yaroslavl one dedicated to Sergiei of Radonezh (1680), whose special devotion to the Trinity is well known ([cf. 43, p. 208-210, fig. 271] and, for his devotion, 
back into more narrative icons of the Hospitality of $\mathrm{Abraham}^{8}$, which often host also visual quotations of truly classical, and therefore heathen motifs, unknown to the Bible, such as a servant slaughtering a bull or calf in the forefront ${ }^{9}$. He is usually depicted in the same attitude and garments of the pre-Christian god Mithras, but without his Phrygian cap [13, pp. 84-85, n. 46; 33, p. 36, fig. 16]. (Exceptions are few) ${ }^{10}$.

Not surprisingly, this problematic addition is dropped in the latest and most unorthodox, highly idiosyncratic several versions of the subject depicted between 1931 and the 1960s by a Russian painter grown up in a Yiddish enclave in Belarus, educated at St Petersburg's art Academy and teaching art in a shtetl at the outskirts of Moscow at the beginning of the Revolution - Marc Chagall (aka Moshe Segal or Mark Zacharovich Šagalov: [60; 61, p. 760, fig. 834; 82, pp. 124-125; 83, p. 4, fig. 6 and p. 16; 7, p. 277; 14, pp. 384-385]). His angels (eloim) always turn their winged backs to the spectator, their faces are in sharp or lost profile (never in full face, or three-quarter), possibly because they are envoys of the Old Testament God, and, like Him, they do not show their faces ([90, pp. 158-177: cf. 14, p. 33]). Thus Chagall's visual interpretation of the biblical passage defies the aniconism at the root of both Judaism and

[81, p. 180]). A bust-length version can be spotted in the top border of the icon of Venerable Alexander of Svir from Vyg [67, pp. 57 and 96, fig. 22] and in many other icons of saints [79, II, pp. 320-321, n. 142], in honour of St. Macarius). Despite its pervasive influence, the Rublev Trinity is by no means the only depiction of the Hospitality of Abraham, as is proven by later icons [56, p. 74, n. 35], often affected by Northern European iconographies (see e.g. [32, pp. 74-77, n. 4 and pp. 96-99, n. 11]) and also by more traditional works of the Pskov school, like a "portable" miniature iconostasis in the Tver art gallery [80, pp. 275-276, n. 169], or even by Novgorod works probably contemporary to Rublev [44, pp. 142-143, fig. 82]. See also an $18^{\text {th }}$-century example from Central Russia [105, pl. 100]. Not surprisingly, outside Russia different compositional patterns are easy to come by: see [50, p. 2]. For a blasphemous variation of Rublev's model, see infra, note 36 .

$8 \quad$ See infra, note 30.

9 Genesis XVIII, 1. 7 barely mentions a calf chosen by Abraham from his herd as the main staple for the meal and states that it is handed over to a young man to prepare it ("to dress it", according to King James' version). While this implies killing the animal first, the text does not mention the action explicitly, as it alludes to any step in the process of preparation for cooking, such as either chopping the slaughtered calf, or putting it on a skew to roast it, seasoning the meat etc. (But see also infra, note 10). The fact is that, unlike a barbecue scene (which would look like a genre-piece), the slaughtering of the bull finds an alluring artistic model in the Mithraic scene, often faithfully reproduced. It thus preserves the aura of both Antiquity and Religion: examples can be found at the Tretyakov Gallery and in St Basil's Cathedral, Moscow and elsewhere [79, I, pp. 68-71, n. 16; pp. 90-91, n. 27, the latter erroneously described by John Lindsay Opie as a version of the Rublev Trinity, whereas the central angel is shown frontally full face, like in most earlier icons]. They are often by the School of Novgorod ( $16^{\text {th }}$ century): two different examples can be seen at Veliky Novgorod, one in the Walters Art Gallery, Baltimore (from Yaroslavl). It is increasingly common in late icons such as the one by Tikhon Filatiev from the Dormition Cathedral of the Moscow Kremlin [101, p. 292, fig. 146]. Such details can be spotted also in the smaller border stories of large icons celebrating angels or saints: see e.g. [32, pp. 128-129, n. 20]; and also in many types of composite icons, such as [79, I, pp. 250-251, n. 110 and II, pp. 448-449, n. 205].

${ }_{10}$ Exceptions include slaughtered calves lying on their backs (e.g. [87, pp. 172-173, fig. 60; 80, pp. 267268, n. 120] ) and/or the servant striking a different attitude ([25, n. 172; 56, pp. 68-69, fig. 29; 101, p. 335, fig. 178; 55, pp. 245 and 381, fig. 83], which is the same Pskov specimen at the Tretyakov Gallery as in [1, pl. 40 and 2, p. 281, fig. 159]), probably deriving from icons of other subjects, yet showing similar festive slaughterings (e.g. [43, p. 191, fig. 248]). Yet another instance from Northern Russia (now at the Tretyakov Gallery) is in [99, fig. 37], where the calf is standing opposite its butcher. While the presence of the calf is irrelevant to Western iconographic traditions and Greek specimens, it is rooted in Hebrew aniconic verbal tradition: [14, pp. 32-33]. 
Christian iconoclasm in a way which is related to the Torah, rather than concerned with the New Testament and its hermeneutical traditions ${ }^{11}$.

Conversely, Ludovico Carracci's picture is a free narrative illustration of the biblical text full of naturalism- what with the majestic oak-tree at the centre, the exotic palm-tree on the left, and Abraham's attire, an odd combination of a red mantle, a violet tunic and the unmistakably dacian trousers first worn by Michelangelo's Moses $^{12}$. This picture's elegant classicism stems from Ludovico's selection of a pre-Raphael devout "mode" or style, very much in the wake of Francesco Francia's, the court painter of the Bentivoglios, the ruling family in Quattrocento Bologna. This is one of Ludovico's recurrent modes in painting ${ }^{13}$. It occurs in other extant pictures of the same series of 13 (now partly lost) to which this one belongs. He painted them for Bartolomeo Dolcini, an obscure canon of the Bologna Cathedral ${ }^{14}$, to decorate his house and they raise some suspicion as to Dolcini's (and/or the painter's) Catholic orthodoxy [77]. In particular, the lost picture of Christ and Nicodemus might be taken as a statement in favour of nicodemism ${ }^{15}$, i. e. of the necessity of hiding the true (Protestant) faith to escape (Catholic) persecution.

Whatever may be of this, it is both fascinating and astonishing to realize that "Rublev's Trinity" must be among Ludovico's several visual sources for his Abraham. Of course Ludovico Carracci never came to Russia - unlike his fellow citizen Aristotele Fioravanti in the previous century [44, pp. 191-194 and 227; 96] —, but he did go to Venice, probably more than once. It is therefore likely that he noticed a specimen of "Rublev's Trinity" amidst the several icons visible there, coming from Crete or other Mediterranean territories and Venetian commercial outposts in the Balkans and beyond. Ludovico was utterly uninterested in the geometrical scheme and in the theological motives underlying Rublev's icon, but he was very much taken by the attitude of the angel at the center, which is Rublev's invention according to Alpatov. He was also struck by the angel's relation to the companion at his right, which is equally retained in his picture, albeit translated into seemingly natural terms. Engrossed in a mute conversation with the former, the latter sits in profile and crosses his ankles, probably misinterpreting the actual position of the legs of his Russian counterpart. All wings are abolished, despite some deliberate subliminal allusions to them, in the shape of the curtain of the tent raised by Sarah behind the angel to the left and in the pink mantle of the central angel, unnaturally raised well

11 The small scenes inserted as a vision in a cloud at the top right-hand corner of each version (showing either Abraham and the three angels at a different stage of their meeting, or Abraham stopped by the angel right before sacrificing Isaac) come from the icon tradition (see above, note 7), both because they show the same characters at different stages of the story, and because they are shown as a vision, like in several icons of visionary saints.

12 For the Dacian attire, see Roman statues of Dacian prisoners in [13, pp. 197-198, nos. 165a/b]. Not surprisingly, Ludovico's prophet Isaiah frescoed in the Church of the Madonna della Pioggia in Bologna is dressed the same way as Michelangelo's Moses. This stands to prove that, following Michelangelo's authority, Dacian and Hebrew garments were interchangeable in Ludovico's mind, even if his Abraham strikes the very same attitude as a Dacian prisoner (but his hair-style is more appropriately "Jewish").

13 On the musical notion of "mode" as applied to Ludovico's art, see [76, esp. pp. 121-122].

14 On the Dolcini series see 11; 77, p. 203 and, as far as preparatory drawings for both extant and lost pictures (albeit not always recognized as such) are concerned, see also [16, p. 175, n. 61; pp. 186-187, nos. 7071; p. 234, n. 107; pp. 263-264, fig. 130; p. 308, n. 16; p. 400, n. 251; pp. 401-402, nos. 252-253; pp. 404-405, nos. 255-256; pp. 442-444, nos. 289-291].

15 Extant preparatory drawings, undetected as such, can be found in [16, pp. 186-187, nos. 70-71]. 
above his shoulder, as if propped against the back of his chair - save that he sits on a backless stool, just like his two companions. (The analysis of Ludovico's extant preparatory drawings proves that this is the calculated result of a long and tortuous creative process) ${ }^{16}$. A major difference between Rublev's central angel and Ludovico's is that the latter's head is placed at the same level as those of his companions, instead of rising higher like in its Russian model. It is a meaningful difference, for Rublev wanted to make it clear that the central angel is the pivotal figure (be he the Father or the Son $)^{17}$ by stressing the circularity of the composition, thus enhancing the interchangeability and equality of the three angels' roles already stated by their nearly identical looks and garments. All this made little sense in Western terms, where the three angels (or persons) had long been shown as all perfectly equal, usually without wings, often in full frontal view and Christ-like looking [48, I, pp. 525-535; 84; 14, figs. on pp. $8,11,12$, fig. 17 on p. 123, fig. 9 on p. 214]. As he painted a religious picture, not a holy icon, Ludovico felt free to alter the attitude of the angel to the right, who turns away from his fellows to politely address Abraham, who is approaching - a very natural invention.

Ludovico also knew that in a Western Christian context, the visual translation of Augustine's Trinitarian commentary summarized in the phrase "tres vidit, unum adoravit"[97, I, p. 88; 5; 74, p. 168] has a different iconographic reference, illustrated by a famous scene in the so-called "Raphael's Bible" in the Vatican Logge [29, pp. 167-168, no. IV3, pl. XX]. Most, if not all the scenes depicted therein, including this one, have been popularized by prints, decorated objects and even faithful reproductions in the same scale and medium, like in the State Hermitage in St Petersburg [29, pp. 8-9]. The most striking feature in this scene is Abraham's attitude. He is not kneeling, Catholic style. He is rather prostrating himself in adoration, in the Eastern and middle-Eastern fashion ${ }^{18}$. Raphael's invention obviously became an inspiration for subsequent painters, especially for a die-hard poussinist like the French Sebastien Bourdon [102, pp. 328-329, no 193]. It is surprising, though, to realize how popular this invention was also with Venetian Baroque painters such as Antonio Balestra, Giovan Battista Tiepolo [68, pp. 334-335, n. 55; 14, fig. 6 on p. 319] and Francesco Guardi. Given that even in the eighteenth century Venice was still the place in Italy to see Byzantine mosaics and icons, these Venetian artists must simply have recognized the old Byzantine iconography behind Raphael's invention, as shown in Italian mosaics, from St. Mark's in Venice to the Cathedral of Monreale and the Palatine Chapel in Palermo.

Still, in the early Christian decorations of catacombs, in the Roman mosaics of Santa Maria Maggiore, in the altarpiece by Nicholas of Verdun at Klosterneuburg [92, I, fig. 85], in the frescoes in the Parma Baptistery, and also in works of art of any medium (painting, drawing, engraving, sculpture, illumination, embroidery and tapestry) from the Netherlands and Germany down to Italy and Spain, different iconographic options are also available, where Abraham is sitting by his herd [48, I, cols. 25-26, fig. 2], walking to meet the strangers or just kneeling in front of them, for the scene is also meant to illustrate "Sarah's conception of Isaac",

\footnotetext{
16 Some are now known only via prints made in the $18^{\text {th }}$ century. For the extant drawings at Chatsworth and Windsor, see [16, pp. 401-402, nos. 252-253].

17 Opinions differ: e.g. [81, p. 180] and [85, p. 159].

18 Some German scholars believe that Raphael was inspired specifically by a lost fresco by Pietro Cavallini in San Paolo fuori le Mura, Rome [29, p. 167]. This may well account for Abraham's attitude.
} 
as a caption in an English $18^{\text {th- }}$ century print puts it ${ }^{19}$, or "the Annunciation of Isaac - The one and trine promises to this one [Abraham] the gift of his offpring" ${ }^{20}$, as the titulus running around Nicholas of Verdun's' panel proclaims.

In Western Christianity, and especially in Catholic terms, the standard representation of the Trinity shows God the Father, Christ (often crucified) and the dove-like Holy Ghost grouped together along a vertical or horizontal line (e.g. [48, I, cols. 525-532; 92, II, pp. $122-$ $124 ; 14$, fig. 36 on p. 296]), like in the upper part of Raphael's dispute on Eucharisty [47, p. 58, fig. 68; 14, fig. 5 on p. 258], which is based on his juvenile invention for a fresco in Perugia [47, p. 23, fig. 30], now badly damaged in the top part featuring God the Father. Virtually contemporary to Rublev's icon, Masaccio's Trinity frescoed in Santa Maria Novella, Florence [46, pp. 56-68, esp. pl. 180] became a local standard, adopted also by Alessio Baldovinetti and Andrea del Castagno among others [98, pl. 9], and elsewhere by Bartolomeo Vivarini in Venice [73, fig. 213; 14, pp. 219-222] and by the young Raphael in Città di Castello at the turn of the century (ca. 1500: [47, p. 8, fig. 12]). In the $16^{\text {th }}$ and $17^{\text {th }}$ centuries it became extremely popular throughout Italy, thanks to the work of great and even excellent artists and it also spread across the Alps [92, I, fig. 4] $]^{21}$. Some icons in the East repeat this invention (e.g. [101, p. 312, fig. 161 and p. 314, fig. 164; 87, pp. 58-59, figs. 13, 15], and, in a broader context, [75, pp. 93-114, esp. fig. on p. 105]), while in turn early Western specimens like Barnaba da Modena's portable altarpiece retain some vague resemblance to icons.

Other frequent and legitimate Trinitarian iconographies in the West show Christ dead in the arms of his Father (to emphasize the human side of Christ's double nature: see [92, II, pp. 233-238 and figs. 768-773, 775-781, 782-792 and 808] ${ }^{22}$, the Trinity crowning the Madonna (a way to combine two different items of faith, reuniting Christ's heavenly and terrestrial parents) ${ }^{23}$, or else the three figures simply sitting or standing together ${ }^{24}$, open to the adoration of spectators both inside and outside the picture. All of these iconographies can be seen in altarpieces and sculptures throughout Western Europe, including pre-Reformation Germany and are based on Medieval examples ${ }^{25}$.

19 A systematic research on internet provides hundreds of examples from all European countries and from different centuries, often already mentioned or reproduced in [14, 48 and/or 92].

${ }_{20}$ The titulus reads: "huic sobolis munus promittit trinus et unus - Annunciatio Isaac".

${ }_{21}$ For the so called Throne of Grace see [92, II, pp. 122-124 and figs. 412-414; 14, pp. 160-164 and 192-200, figs $25-27$ on pp. 161-163, fig. 7 on p. 222 , figs. $11-12$ on pp. $226-227$, fig. 13 on p. 327].

22 Ludovico Carracci painted a stunning picture of this subject [34, pp. 73-74, n. 34]. See also note 25.

23 For Western examples see [48, II, cols. 671-675] and [92, IV.2, pp. 147-154 and figs. 735, 741-742, 744a and 745-750] and also note 25. The Crowning of the Virgin by the Trinity is depicted also in some late Russian icons: e.g. [32, pp. 112-113, n. 15] (above Christ holding the animula Virginis), or in narrative icon frames [101, p. 309, fig. 159] and even menologia ([63, pp. 282-283, n. 129], at the top, in the centre). Endless examples can be found in [79, III], as the volume is entirely devoted to $19^{\text {th }}$-century Russian icons. See also infra, note 33 .

${ }_{24} \quad$ Sometimes there are just two of them, usually Father and Son, without the Holy Ghost (what Boespflug calls a "Binity" [14, pp. 114-115 and 158-159]). Occasionally the Madonna is represented in the stead of the latter: see e.g. [92, II, figs. 768-782]. As for the so called "Quinity of Winchester", see [14, pp. 144-145 and fig. 16 on p. 145], and [92, I, fig. 7].

25 Full information on such iconographies, as well as on any representation of God's image, is expressed in a discursive rather than systematic manner in François Boespflug's thorough theological study on the image of God [14, pp. 232-237 and figs. 15-16 on pp. 230-231, figs. 18-21 on pp. 234-236, fig. 7 on p. 260, 
These Western European iconographical standards are partly matched by the comparatively rare Russian and Eastern European type known as the New Testament Trinity or Paternitas (Otechestvo)( [54, pp. 25-26, fig. 31; 87, pp. 119, 120-121 (fig. 38), 130-131, 195-197 (fig. 70); 94 , p. 138, n. 62, fig. 110; 101, p. 186, fig. 64, p. 331, fig. 176 and p. 339, fig. 180], most of them placed at the top of icons of the Mother of God; [100, p. 153, n. and fig. 127], within a liturgical icon; [88, p. 23], at the top of the iconostasis; [55, p. 186, fig. 36], same as [43, p. 167, fig. $218 ; 45$, n. 36; 14, fig. 21 on p. 155] $)^{26}$, rooted in Greek Byzantine tradition ${ }^{27}$. Just like the icon showing Father and Son sitting on thrones next to one another (Synthronon), a dove fluttering between them ([58, p. 48, fig. $23 ; 43$, p. 139, fig. 181], at the very top of the picture; $[100$, p. 148 , fig. 52 , p. 215 , fig. 79 , p. 263 , fig. 115], in all instances at the very top of the picture; [67, pp. 283 and 102, fig. 42], at the top of the icon-case; [32, pp. 176-177, fig. 34], as a vision; [63, pp. 262-263, n. 119; 45, n. 57], at the top of a Resurrection icon), it is most often present in late icons and in areas close to Italy or under Venetian influence (the Balkans, especially Serbia, and Crete: [104, p. 9; 4, p. 68, fig. 99; 63, pp. 68-69, n. 19; 26, pp. 184-185, n. 47]), at the outskirts of Russian orthodox influence, in places where Western and Eastern iconographies would meet and mingle together (e.g. [24; 75, pp. 103-106]) ${ }^{28}$. In fact, the Otechestvo was explicitly condemned in the 1667 Council of Moscow as "absurd and against verisimilitude at the utmost degree, for nobody has ever seen God the Father, as he has no flesh" (quoted in [85, p. 156, note 2] and anticipated in [31, p. 136]; see also [75, pp. 98-104]). A century earlier the XLI chapter in the Stoglav had been peremptory: "Painters shall reproduce ancient models, those by Greek iconographers, by Andrei Rublev and other well-known painters. Above it should be written: "Holy Trinity". Painters should never follow their fancy in any respect" [31, p. 107], a concept further reinforced in chapter XLIII [31, pp. 133-136]. Even so, in the cathedral of the Nativity of the Virgin at Suzdal the New Testament Trinity is frescoed most prominently in its vault and has been recently imitated ${ }^{29}$, while in some late icons, as well as in some iconostases, the New Testament Trinity is superposed to Rublev's ${ }^{30}$.

figs. 42-44 on pp. 301-303, fig. 11 on p. 324 for the so called "Compassionate Father"; figs. 24-29 on pp. 240244 and figs. 31-32 on pp. 246-247, fig. 37 on p. 296 for the Trinity Crowning the Madonna; pp. 177-186 and figs. 5-9 on pp. 178-182, fig. 1 on p. 210 for the synthronon].

26 A few more examples can be found in the State collection of the Hermitage, in the Museum of Russian icons at Clinton (USA) and in the Sorø Kunstmuseum in Denmark, and finally in the Smolensky Cathedral of the Novodevichy monastery and in the Museum of the Kirillov-Belosersky monastery in Vologda (both by Zhdan Dementiyev, the latter dated 1630). Many are reproduced (often without hints of their current locations) in the web, in dedicated areas of Pinterest and Wikimedia Commons (Google Art Project), as well as in www.iconrussia.ru/eng/icon.

$27 \quad$ Byzantine examples are obviously earlier: see the fresco in the Church of Our Lady, Koubellikidi Kastoria, Greece (ca. 1260). See also [14, figs. 8-9 on pp. 113-114 (both examples are Greek and date to the $11^{\text {th }}$ century) and [14, fig. 16 on p. 122 (same as p. 104 Greek, $13^{\text {th }}$ century)].

28 A particularly odd icon from former Czechoslovakia is reproduced in [93, fig. 38]: it depicts the martyrdom of St. Stephen, where the stone-throwers are dressed in contemporary German clothes (indeed they look like Lutheran clergy). The New Testament Trinity is placed at the top of the scene, sitting on clouds. ${ }_{29} \quad$ It has been copied in the Lavra Mambre, or Monastero de la Santa Trinidad in Guatemala, established only a few decades ago. It is probably fair to add that the local hegumen of the church is a former Catholic nun, later converted to Orthodoxy. The website is still available, but is now marked as unsafe for browsing. 30 This is the case of both the iconostasis in the cathedral of the Holy Trinity in the Ipatiev Monastery at Kostroma and of the one of the Trinity and St. Sergius at Sergiev-Posad (for the latter, see [81, fig. 113] 
The Stoglav (1551) is virtually contemporary to the much longer Council of Trent (1545-1563). For all their obvious differences (Emperor Charles V had a much lesser say in Trent than Czar Ivan IV had in Moscow [15; 71, pp. 138-149]), both councils share some liturgical and theological positions. In particular, they both defer to the individual bishops the monitoring of orthodox iconographies in the churches of their diocesis, as well as the removal and destruction of the wrong, inept or inappropriate images [31, pp. 135-136]. Bishops like Cardinals Gabriele Paleotti in Bologna [72], Carlo and Federico Borromeo in Milan (and Rome) $[17 ; 18 ; 19]$ and theologians like Jan Vermeulen (Johannes Molanus) teaching at the Catholic University of Louvain in the Flanders [64] composed treatises of various length and detail, often in Latin, often unfinished, to give guidelines to fellow bishops, priests and patrons - and, via them, to painters as well. Only Molanus discusses the representation of the Trinity in full, at the very beginning of his book [64, pp. 16-19] ${ }^{31}$. Molanus relies on earlier Western theologians and, unlike Paleotti, on Latin rather than Greek Patristic. Even so, he acknowledges as legitimate the representation of the Trinity in the guise of three men (not angels), for this is the way it was revealed to Abraham, according to Augustine's interpretation (cf. [14, pp. 186-192 and figs. on pp. 8, 11, 12, fig. 17 on p. 123, fig. 9 on p. 214]). As for the Ancient of days or antiquus dierum ( $\delta \pi \alpha \lambda \alpha$ ıó $\tau \omega v \dot{\eta} \mu \varepsilon \dot{\varepsilon} \rho v$ ), as seen by Daniel and John

and for Rublev's work in it, see [81, pp. 188-193]). In both instances the Otechestvo is placed at the center of the highest tier, on the same vertical line as the medallion featuring the Theotokos (Mother of God, or of the Saviour) on the tier below and the Christ in Majesty on the central tier, while the Old Testament Trinity is on the lowest level, at the side of the royal doors. In fact, in the case of the Trinity-Sergiev Posad Monastery, there are two different specimens of Rublev's Trinity, placed at either side of the royal doors, together with a Mandylion, a Hodigitria, a Christ enthroned, a dormitio Virginis, and the portrait icon of a saint framed by episodes from his life. Also the $17^{\text {th }}$-century iconostasis of the Transfiguration Cathedral at the SaviourSt. Euthymius Monastery in Suzdal shows the same pattern, with the Otechestvo at the centre of the upper tier and the variation of Rublev's Trinity as Hospitality of Abraham at the very far left of the lowest tier (see [33, general scheme at pp. 24-25, and individual pictures at p. 36, entry and fig. n. 16 and p. 55, entry and fig. n. 48]). Another example comes from Sviyazhsk [87, pp. 130, 133 and 136]; see also [101, p. 42, fig. 4]). The iconostasis at Kolomenskoe has a different iconographical pattern: the New Testament Trinity as Synthronon is placed at the center of the upper tier, above the icon of Christ in Majesty hung right above the royal doors in the third tier, while the Old Testament Trinity (Rublev type) is on the second tier, to the left. Even portable iconostases often show similar iconographic elements and dispositions: see e.g. [63, pp. 274-276, n. 119], where God the Father is at the center of the iconostasis, just under the Crucifixion but above the image of the Madonna, which is on top of a Christ in Majesty, while an Old Testament Trinity is placed next to the Royal doors. For the general liturgical scheme underlying the disposition of icons on Russian iconostases, see also [2, pp. 74-86; 40; 70, pp. 59-66] and [86, pp. 235-241], where the Old Testament Trinity is placed at the top of the iconostasis, at its very center. It is fair to add that the Rublev Trinity is often present in the lower tier of Russian iconostases: see also the one in Cathedral of the Dormition in the Trinity and St. Sergius Laure [12, fig. 7]. Obviously enough, this is not the case in Greek churches. Even so, icons of the Hospitality of Abraham are not hard to come by in Greece, for instance at the Kykkos Monastery in Cyprus. Occasionally, individual icons can combine both types of Trinities, showing the New Testament Trinity on top of the Old one (often depicted as a Hospitality of Abraham): see e.g. [25, fig. 146] (a portable polyptich) or [50, p. 1] (in this case, a $15^{\text {th }}$ - and $16^{\text {th }}$-century icon from Krakow, the New Testament Trinity is composed by God the Father and Christ as the Man of Sorrows, without the Holy Ghost). For the Western iconography of the Trinity including the Man of Sorrows, see [92, II, pp. 219-224 and figs. 767-797].

$31 \quad$ Paleotti never published his entire treatise, having printed only its general introduction and the list of contents of the whole work. Parts of the unpublished sections, written in Latin, have survived a fire of the Paleotti family archive, but their edition, albeit announced, has not come to light yet [10, pp. 213-223]. 
in the Revelation (cf. e.g. [79, II, pp. 468-469, n. 215] and the late Greek icon by Thomas Vathas discussed in [52, p. 162, n. 35], where he is depicted according to Dürer's engraving for the Book of Revelation) ${ }^{32}$, he is the prerequisite to allow the representation of God the Father within and without the "New Testament Trinity" ([101, p. 347, fig. 183], and, more specifically [101, p. 279 , fig. $133 ; 32$, pp. 108-109, fig. 14 and pp. 114-117, fig. 16; 88, p. 28; 43, p. 239, fig. 313]), often on top of Marian icons ${ }^{33}$ and above Christ in the Last Judgement ([105, p. 281, same as 43, p. 227, fig. 296; 56, p. 198, fig. 48; 79, I, pp. 232-233, n. 101], showing also a synthronon $[50, \text { p. 40]) })^{34}$. Molanus quotes earlier theologians both in its favour (on the ground

32 For earlier Byzantine representations, see e.g. [25, figs. 32 and 88 (within a New Testament Trinity) and notes 27 and 34]. In the West, the representations of God the Father are countless: see e.g. [48, II, cols. 166170; 14, fig. 19 on p. 125]. On the antiquus dierum as God the Father not only in the representation of the Trinity, but also of the "Binity" (i.e. Father and Son without the Holy Ghost, see [14, pp. 114-115 and figs. 2324 on pp. 158-159]).

33 In the oklad of a late (1789) Bulgarian icon of the Mother of God Odigitria [66, pp. 106-107, n. 35] the Greek inscription at both sides of God's head reads 'O ПANTOKPAT $\Omega$ P $\Theta E O \Sigma$, even if the image looks closer to the antiquus dierum, than to Christ and therefore similar to other Marian icons such as the one in [43, p. 129, fig. 168], where the figure of the Mother of God Panagia and her Son (portrayed in a medallion on her breast, like in the Platytera) is placed under the blessing figure of God the Father in the guise of the Antiquus dierum, a small dove in a medallion laying on his breast. Cf. also [36, p. 96, n. 60] (from Albania). Beside the simmetry in composition, it is worth remarking the additional iconographic motif of the New Testament Trinity, Father, Holy Ghost and Son being placed along the same vertical line. There are several other late ( $18^{\text {th }}$ century) Marian icons where, beside Mary, the New Testament Trinity is also represented or alluded to (for Western examples, see [92, I, figs. 96-97 and 101-105]; for Eastern ones, see [79, I, pp. 206-207, n. 85; 79, II, pp. 496497, n. 229], apart from the obvious occasion of her Crowning [79, II, pp. 474-475, n. 218; 36, p. 94, nos. 56 and 57, at the top of the icon]. The antiquus dierum is often present in late ( $17^{\text {th }}$ century) Annunciation icons, either overseeing the scene from the sky above [79, I, pp. 88-89, n. 26]; see also the Novgorod Annunciation of 1130-1200 in the Tretyakov Gallery [54, pp. 9-10, fig. 6] where Jesus Christ stands for the Antiquus Dierum, as was later decreed by the 1667 Moscow Council), or more often instructing Gabriel before he leaves to meet Mary [79, I, pp. 76-77, n. 19; 79, II, pp. 466-467, n. 214; 25, fig. 168]. He occurs even in "metaicons" of this subject, such as those featuring venerable characters adoring the Annunciation icon (e.g. [79, I, pp. 164-165, n. 64; pp. 214-215, n. 89; pp. 256-257, n. 113]). Notwithstanding the 1667 Moscow Council, he is featured most often in many later Marian icon types (e.g. [79, II, pp. 296-297, n. 130; pp. 352-353, n. 158; pp. 400-401, n. 181; pp. 414-415, n. 188; pp. 422-423, n. 192]).

$34 \quad$ God the Father is placed on top of a print showing the Deposition/Entombment of Christ designed by the iconographer Paissi (see note 7), a dove being placed in mid-air [67, pp. 44 and 93, fig. 10]. This is obviously a Trinitarian image (see also the previous note and [cf. 14, fig. 45 on p. 305 and fig. 4 on p. 317]). The dove is not present in a different type of icon showing God the Father under the Old Testament Trinity (Rublev type) and over the Man of Sorrow held by his Mother [94, p. 140, n. 78, fig. 92]. Not surprisingly, he is also present in icons featuring St. John the Baptist, both individually as the Angel of the Desert [79, I, pp. 114-115, n. 38; pp. 270-271, n. 120; 79, II, pp. 472-473, n. 217], or while baptizing Christ, as is often the case also in Western altarpieces (for this iconographic subject, see [92, I, pp. 127-145 and figs. 356-358; 14, fig. 17 on p. 79, fig. 12 on p. 118, fig. 13 on p. 119, figs. 17-19 on pp. 149-151 and fig. 1 on p. 289]; for Eastern examples, see [79, II, pp. 410-411, n. 186]; and also [25, figs. 152 and 160], whereas fig. 159, notwithstanding its provenance and dating, coinciding with the latter, does not include God the Father). He can be seen in many icons related to Christ deeds, most specifically his Crucifixion [79, I, pp. 106-109, n. 35; 79, II, pp. 440-441, n. 201; pp. 536537, n. 248; 63, pp. 66-67, n. 18 by Theodor Poulakis and pp. 300-301, n. 105]; and for wholly heretic versions as discussed in [99, pp. 104-106 and 75, pp. 94-109], see [94, p. 161, n. 249 and fig. 81], same as [99, fig. 39b] or the Maries visiting his empty sepulcher [79, I, pp. 458-459, n. 210)]. The absence of the dove prevents them from being fully Trinitarian images (on the Binity, see notes 24 and 32). God the Father is often to be seen in the upper part of late icons related to the Prophet Elijah [79, II, pp. 332-333, n. 148; pp. 388-389, n. 175; pp. 542-543, n. 251] or some orthodox saints (like Boris and Gleb, see [87, pp. 142-143, n. 47]), especially if 
that painters can paint whatever holy writers have described) and against it, only to state that the Council of Trent suggests a solution that encompasses both positions, admitting such a representation only under special conditions. (The 1667 Council in Moscow considered it a representation of Christ ${ }^{35}$, not of God the Father, which is probably why nowadays Catholic groups in Eastern Europe peddle it as a sort of new missionary icon vaguely resembling the Christ Enthroned or in Majesty ([92, III, pp. 222-230 and 233-249, figs. 628-654 and 662721], with legends in Latin) ${ }^{36}$. Molanus also lists a number of Trinitarian representations that should never be allowed, such as a figure with three heads, or a head with three faces [64, pp. 17-18], which nevertheless had been very popular in the Middle Ages throughout Europe [48, I, cols. 532-533; 22; 59; 84; 14, pp. 204-206, fig. 33 on p. 249, fig. 24 on p. 278 and fig. 26 on p. 282 ${ }^{37}$. They stayed popular in Renaissance Florence (e.g. [65, fig. 47]), for a three-faced head features even at the centre of the vault of Eleonora da Toledo's private chapel in Palazzo Vecchio [62, pp. 77-79 and pl. VI]. This only stands to prove how the Medici court was quietly dissenting from the Catholic orthodoxy in many ways [35].

Molanus also condemns heretical representations of the Trinity he had seen in Carmelite and Carthusian monasteries in France and the Flanders, where it was represented as if engendered by Mary [64, pp. 17-18]. This iconography seems to have been effectively removed from Catholic churches during Counterreformation ${ }^{38}$, only to reappear today under a new

protecting a given monastery [79, I, pp. 264-265, n. 117], although even in very late $19^{\text {th }}$-century icons the figure of Christ is also featured in the same circumstances, following truly Orthodox precepts [79, I, pp. 680681, n. 317]. Finally, the Antiquus dierum may occur in icons of St. Sophia enthroned [94, p. 140, n. 81, fig. 98], in the ones celebrating the Creation of the World [101, p. 315, fig. 165] or the six days of Creation ([79, II, pp. 478-479, n. 220]; at earlier dates, in the $16^{\text {th }}$ century, the God of Creation was often shown as a younger man, like Christ: see e.g. [87, p. 15]), the Credo [94, p. 153, n. 187 and fig. 116] and the Last Judgement, where he usually sits or hovers above Christ the judge (see in the text here, and, for an earlier mid-15 $5^{\text {th }}$ century specimen, also [2, p. 280, fig. 136]). Given that in the last icon type either the dove, or the open book of the Scriptures or both are also present along the same vertical line, clearly it also works as a Trinitarian image. Sometimes the New Testament Trinity resurfaces from within entirely different compositions, such as The grapevine icon by the Cretan painter Vittore, dated 1674 ([4, p. 10, fig. 11]; one more Cretan example in [25, fig. 38]) or the Death of the just man and of the sinner [79, II, pp. 344-345, n. 154]. See also the previous note. All this is evidence of obvious divisions and dissent within the Orthodox church. Given the growing number of such images throughout the $18^{\text {th }}, 19^{\text {th }}$ and $20^{\text {th }}$ centuries, Western influence is obviously responsible for this, as is proven also by the increasingly westernized style of very late icons (see e.g. [79, II, pp. 428-429, n. 195], showing Crucifix, Lord Sabaoth and the Kiev saints).

35 Calvin agrees: [21, pp. 23-60, esp. 55-60].

36 While the Polish site where I saw it originally in the late Spring of 2018 is no longer to be found, the image is still present in different websites, most notably within a collection of "schlock icons" gathered in www.orthodoxchristianity.net (on p. 24) Cf. with orthodox icons such as [43, p. 218, figs. 284 and 285 or 55, p. 258, fig. 90 , by Theophanes the Greek; p. 284, fig. 99 and p. 292, fig. 102, by Andrei Rublev]. It is worth mentioning here that in the same site cited above several other unacceptable icons can be found, devoid of any orthodoxy by either Eastern, or Western standards, e.g. the Rublev Trinity revisited, with no angels, substituted by Christ sitting between his Mother and the Magdalen (p. 10) and, on the same web page, a threeheaded Trinity obviously reminiscent of some Western specimen, despite the fact that it had already been formally condemned by the Catholic Church. See also [99, p. 105 and pl. 39a], depicting the Vision of St Peter of Alexandria, where the Trinity is represented by Christ as a three-headed angel.

37 On the heathen, pre-Christian origin of this iconography see [78].

38 One anonymous sculptural example from Western Prussia of $1390 \mathrm{ca}$. survives at the Germanisches Nationalmuseum in Nürnberg. It combines the Trinitarian theme with Mary Mater Misericordiae, as the 
disguise in minor sectarian groups of Catholic stock in France ${ }^{39}$. The legitimate image of the Crowning of the Virgin (occasionally shown as Immaculate) by the Trinity may be the source for this heretical variation, or perhaps a record of this earlier, heretical link between Mary and the Trinity.

The fact is that images are much more ambiguous, various, rebel to codification than words, especially where the representational codes of mimesis are superimposed to the ones of religious orthodoxy to define the quality of a picture. (Quality is essential to holy images. Both Catholic and Orthodox theologians agree that inept artists should never paint them, for their work, no matter how well-intentioned, verges on visual blasphemy: [cf. 31, p. 135; 72, pp. 265-267, 370-382, 390-397]. Images pose a semiotic problem, obliquely confirmed by the very failure to publish complete, systematic Counterreformation treatises on them, let alone an "Index of forbidden images" to match the "Index of forbidden books ${ }^{40}$. Ut pictura poesis (painting and poetry are alike) and $u$ t rhetorica pictura (painting is like rhetoric) are useful tenets for lay Renaissance and Baroque art theoreticians as well as for artists in the West [57], but they are grossly misleading in many respects. This is why Cardinal Paleotti fell back on medieval scholastic tradition instead, advocating a general semiotical interpretation of religious communication on the ground that images, being natural representations, are universally intelligible, whereas the power of words is limited by the diffusion of the language in which they are uttered [72, pp. 139-149]. On this score he would agree with Jesuits, whose problem was the conversion of indigenous peoples outside Europe. Their languages were unknown, structurally foreign to any European idiom, culture and psychology. It was hard to learn them, therefore images looked like an easy alternative solution for communication, especially as they were already used successfully in Jesuit missions across Europe (e.g. [37, pp. 161-190 and passim; 23; 38]).

Jesuit optimism was largely unjustified, though, for images, no matter how mimetic, have their own semiotic codes, just like languages, and they do not extend much beyond the culture that has generated them (which is why they worked in Europe, where they were produced). Today it is an acknowledged fact that American Indians, Chinese and Japanese have real trouble at "seeing" painted shadows. In fact, they do not use them in their art. In Western pictures chiaroscuro is often essential to the mimetic quality of the image, but is hardly intelligible to them [39, pp. 323-328]. It is both a perceptional and a cultural problem. More serious cultural misunderstandings were at stake with highly organized, hierarchical and very refined cultures such as the Far Eastern ones. By European standards, the notion that showing the images of the Crucifix or of regularly footed female saints was utterly insulting for a Chinese Mandarin was totally unpredictable [37, p. 323]. Thus visual communication often

wooden statue, when open, shows the Throne of Grace at the center, while on both sides the faithful look up in prayer. A similar French statue is discussed in [14, pp. 202-204, esp. figs. 26-27]. Oddly enough, despite being a former Dominican friar, Boespflug seems to find nothing wrong with this iconography and postulates French royal and princely support for it [14, pp. 202-204].

39 In the church of Notre Dame de la Trinitè at Blois (France) there is a $20^{\text {th }}$-century polychrome statue of Mary, bearing on her chest three symbols allusive to the three persons of the Trinity. Despite its less than mediocre artistic quality, it is used by Trinitarian groups for the covers of their books [27].

40 Indeed the Index imaginum prohibitorum is a project long-cherished by Cardinal Paleotti, but never come true, as it is clearly impossible to register, codify and predict all the possible iconographic variations of any given religious subject-matter, whether acceptable or not. 
proved to be a hindrance rather than an asset in Jesuit missions around the world. Eventually Catholic missionaries had to take their time and switch to studying non-European languages and cultures (and teach their own) in order to communicate effectively with the natives.

Even within Europe images could be highly misleading, in more ways than one. Thus in 1573 the Inquisition in Venice prosecuted Paolo Veronese for depicting German halbardiers in his Last Supper (subsequently renamed Supper at the House of Levi) for the Refectory of san Giorgio in Alga. Their very presence elicited suspicions of subliminal pro-Lutheran propaganda [75, pp. 172-173; 42]. Conversely, inquisitors at times happened to overlook borderline iconographies. I believe that this is the case for some of Ludovico Carracci's late paintings, most notably for his Crucifixion of 1614 [34, pp. 157-158, n. 72]. The mode adopted here is very different from the one in his Abraham and the three angels. His deeply pathetic, anticlassical style clearly evokes German pictures, such as Grünewald’s Crucifixion at Isenheim, not only because of the emaciated, tormented, unusually graceless figure of Christ, but also because of the shape of the cross, its arms roughly hewn, still covered by tree-bark. It follows German rather than Italian models - where the cross is always debarked, neatly cut, squared and polished [75, pp. 159-162]. Ludovico, especially in his late years, was very much taken by German art, be it Dürer, Cranach or some anonymous engraver [77, pp. 201-202]. Such artistic penchants were not necessarily innocent or naif, at the time of the religious confrontation between Catholic South and Protestant North. Especially if the picture shows the Crucified Christ not amidst the purging souls of the Purgatory (as erroneously stated in some old guidebooks), but amidst the Old Testament patriarchs in the Limbo, as Gail Feigenbaum correctly pointed out years ago [34, pp. 157-158, n. 72]. It is a rather innovative iconography, very different from the resurrected Christ in the Harrowing of Hell, or Anastasis - a subject also depicted by Ludovico in Bologna a few years earlier, in a picture whose Catholic orthodoxy has been questioned by Feigenbaum [34, pp. 131-132, n. 60]. Indeed the Crucifixion altarpiece posed some problem if, only a few years after being installed on the high altar of the Church of Santa Francesca Romana in Ferrara, it was suddenly removed and placed in the somber darkness of a lateral chapel, where it has stayed ever after. His patron, a monk, may have wished to use this altarpiece for propaganda, to foster the conversion of the large Jewish community resident in Ferrara, at a time when the city was no longer the capital of the liberal Este duchy, having recently been annexed to the Church state. Even so, this image is somewhat reminiscent of motifs and of the spirit in the Dogmenbilder (dogmatic images) invented by Cranach to give visual body to the Lutheran ground belief that men are saved by their faith and the Grace of God, not by their own deeds [90, pp. 357-360, 402; 75, pp. 157-170; 14, pp. 270-273].

The three Carracci have long been considered the heralds of Catholic orthodoxy in Bologna and in Italy. A special relationship between them and their Bishop, Gabriele Paleotti, has often been assumed and even taken for granted. New historical evidence on the Carracci family and their relations seems to point to a different direction. It is a fact that Paleotti as a patron preferred late Mannerist artists to the Carracci, whom he very seldom employed and then only under the most unfavourable circumstances. Deep, albeit unuttered concerns on Ludovico's orthodoxy may also be the real reason why he never obtained a much-sought-after commission for an altarpiece in St. Peter's Rome, even if this is generally credited to his style, incredibly various, but often too hard and rigid in religious paintings [77]. 
His pictures, like all images, were and are subject to different readings and interpretations, they could and can generate misunderstandings and/or convey inconvenient messages. This is why a radical Lutheran like Andreas Bodenstein, known as Karlstadt or the French Reformer Jean Calvin rejected all sorts of religious imagery, leaving art to secular life only [14, pp. 273-278]. In areas influenced by Calvinism, from Switzerland to the Netherlands and the Anglican Britain of Bishop Thomas Cranmer, painting is confined to secular topics only, where it is its duty to be true to nature, portraying the beauty of the world through its accurate, meticulous representation [ 75 , pp. 129-132]. Portraiture in all its forms (of people, pets, mansions, landscapes, vessels, still-lives etc.) is its true essence; it serves a function and a purpose which is both social and moral. It shows the only truth that can be seen and shown - the world in all its manifestations, occasionally rising to a moral or allegorical dimension. This may well be a way to praise the Lord indirectly through his creations, but in fact it confirms that the eye can only capture the world and human activities, whereas only the word is the true manifestation of God, in the Book as well as in its several verbal interpretations. Word and image are not interchangeable - Calvin is a by-product of Scholasticism, not of Platonism and seems to revive concerns already expressed by Bernard de Clairvaux at the beginning of the $12^{\text {th }}$ century. The eye cannot convey the intellectual truth which is revealed by the Word ("In the beginning was the Word [...] and the Word was God": John's Gospel I,1). Even icons, for all their abstraction, are misleading, for aniconism is the prerequisite, the necessary visual silence that lets the Word be heard. No line, no colour, no representation, for they are all human fabrications. The language of Eden may be lost, but speech is God's own doing, even - or especially — after Babel. In a way, this stresses the continuity between the Old and the New Testament, as it objectively promotes a positive revival of Old Testament tenets. Even so, within Christianity ascetic aniconism is marginal and has never got the upper hand. For all their ambiguity (or possibly because of it) images have won not only the day, but for good, partly as an aid to mysticism, partly as a silent homage to pragmatism.

\section{References}

1. Ainalov D. Geschichte der Russischen Monumentalkunst zur Zeit der Grossfürstentums Moskau. Berlin; Leipzig, de Gruyter Publ., 1935. 144 p. + 73pls. (in German).

2. Alpatov M. V. Treasures of Russian of the $11^{\text {th }}-16^{\text {th }}$ Centuries (Painting). Leningrad, Aurora Publ., 1971. $288 \mathrm{p}$.

3. Alpatov M. Le icone russe. Problemi di storia e di interpretazione artistica. Turin, Einaudi Publ., 1976. 290 p. (in Italian).

4. Bandera Viani M. C. Venezia - Museo delle Icone bizantine e post bizantine e chiesa di San Giorgio dei Greci. Bologna, Calderini Publ., 1988. 130 p. (in Italian).

5. Bartelink G. J. M. Tres vidit, unum adoravit - formule trinitaire. Revue des Études Augistiniennes, vol. 30, 1984, pp. 24-29 (in French).

6. Belting H. Il culto delle immagini - Storia dell'icona dall'età imperiale al tardo Medioevo. Rome, Carocci Publ., 2001. 695 p. (in Italian).

7. Beltramo Ceppi Zevi C.; Meyer M. Chagall delle meraviglie. Géneve; Milan, Skira Publ., 2007. 332 p. (in Italian).

8. Bentini J. et al (ed.). Pinacoteca Nazionale di Bologna. Catalogo generale, vol. 2: Da Raffaello ai Carracci. Venice, Marsilio Publ., 2006. 494 p. (in Italian).

9. Bertoli B. I mosaici di San Marco - Iconografia dell'Antico e del Nuovo Testamento. Milan, Electa Publ., 1986. 210 p. (in Italian).

10. Bianchi I. La politica delle immagini nelletà della Controriforma - Gabriele Paleotti teorico e committente. Bologna, Ed. Compositori Publ., 2008. 254 p. (in Italian). 
11. Bianchi I. Note sul collezionismo Bolognese del Seicento attraverso documenti inediti: Bartolomeo Dolcini e i "quadri di pittura fatti per mano di Ludovico Carrazzi". Perini Folesani G.; Ambrosini Massari A. M. (eds.). Riflessi del collezionismo tra bilanci critici e nuovi contributi. Florence, Olschki Publ., 2014, pp. 145-158 (in Italian).

12. Bird A. Storia della pittura russa. Turin, Allemandi Publ., 1987. 332 p. (in Italian).

13. Bober P. P.; Rubinstein R. O. Renaissance Artists and Antique Sculpture A Handbook of Sources. London; Oxford, Harvey Miller and Oxford University Press Publ., 1986. 522 p.

14. Boespflug F. Le immagini di Dio - Una storia dell'Eterno nell'arte. Turin, Einaudi Publ., 2012. 581 p. (in Italian).

15. Bogatyrev S. Reinventing the Russian Monarchy in the 1550s: Ivan the Terrible, the Dinasty and the Church. Slavonic and East European Review, 2007, no. 85, pp. 271-293.

16. Bohn B. Ludovico Carracci and the Art of Drawing. New York, Harvey Miller Publ., 2004. 642 p.

17. Borromeo C. Instructionum Fabricae et Supellectilis Ecclesiasticae libri II (1577), reprinted with a basic commentary in Barocchi P. (ed.). Trattati d'arte del Cinquecento. Bari, Laterza Publ., 1960-1962, vol. 3, pp. 1-113, and with an Italian translation: Vatican, Libreria editrice Vatican-Axios Group Publ., 2000 (in Latin and Italian).

18. Borromeo F. Della pittura sacra, libri due. Pisa, Scuola Normale Superiore Publ., 1994. 148 p. (in Italian).

19. Borromeo F. De pictura sacra (1624), reprinted in Sora, Camastro Publ., 1932. 116 p. (in Italian).

20. Bovini G. I mosaici di Ravenna. Milan, Silvana Editoriale Publ., 1957. 58 p. + 46 pls (in Italian).

21. Calvino G. Institutio Christianae Religionis. Génève, R. Stephani Publ., 1559. 564 p. (in Latin).

22. Castagno P. La Trinità eucaristica nella Pieve di San Giovanni ai Campi di Piobese Torinese. Alcune considerazioni su un affresco inedito. Carignano, Associazione Progetto Cultura e Turismo. Available at: www.pievedipiobesi.it/files/laffresco_della_ss_trinita_nella_pieve_di_piobes.pdf (accessed 25 January 2019) (in Italian).

23. Catellani A. Scrivere e disegnare la meditazione. Note semiotiche su pratiche spirituali e testi guida nella cultura del Seicento. E|C, 2008, pp. 1-14 (in Italian).

24. Chatzidakis M. Marcantonio Raimondi und die post-byzantinisch kretische Malerei. Etudes sur la peinture postbyzantine, 1976, no. 3, pp. 147-161 (in German).

25. Chatzidakis M.; Djuric V. Les icônes dans les collections suisses. Genève, Musée d'Art et Histoire Publ., 1968. 150 p. (in French).

26. Chatzidakis N. Venetiae quasi alterum Byzantium. Da Candia a Venezia. Icone greche in Italia, XV-XVI secolo. Athens, Fondazione per la cultura greca Publ., 1993. 214 p. (in Italian).

27. Cirimotic L. La Madonna e la Trinità. Fondamento biblico della consacrazione di Maria. Conegliano, Ancilla Publ., 2015. 204 p. (in Italian).

28. Cormack R. Painting the Soul - Icons, Death Mass and Shrouds. London, Reaktion Books Publ., 1997. 248 p.

29. Dacos N. Le Logge di Raffaello. Istituto Poligrafico e Zecca dello Stato Publ., 1986. 367 p. (in Italian).

30. Delivorrias A. Guide to the Benaki Museum. Athens, Karidakis Bros. Publ., 1980. 200 p.

31. Duchesne E. Le Stoglav ou les cent chapitres. Paris, E. Champion Publ., 1920. 292 p. (in French).

32. Evseeva L.; Lisitsina O. L'icona russa Preghiera e misericordia. Rome, Moscow, Andrey Rublev Museum Publ., 2017. 191 p. (in Italian and Russian).

33. Evseeva L. M.; Komaschko N. I. Ikonostas preobrazhenskogo Sobora Spaso-Evfimieva monastiria (The Iconostasis of Preobrazhensky Cathedral of Spas-Evfimiev Monastery). Moscow, Andrei Rublev Museum Publ., 2017. 66 p. (in Russian).

34. Feigenbaum G. Entries. Emiliani A. (ed.). Ludovico Carracci. Bologna, Nuova Alfa Publ., 1993. 365 p. (in Italian).

35. Firpo M. Gli affreschi di Pontormo a San Lorenzo. Eresia, politica e cultura nella Firenze di Cosimo I. Turin, Einaudi Publ., 1997. 446 p. (in Italian).

36. Forestier S. et al. Tresors d'art albanais. Icônes byzantines et post-byzantines du XII au XIXe siècle. Paris; Nice, Rèunion des Musées nationaux; Musée National Message Biblique Publ., 1993. 140 p. (in French).

37. Freedberg D. The Power of Images. Studies in the History and Theory of Response. Chicago; London, University of Chicago Press Publ., 1989. 534 p.

38. Gentilcore D. Accomodarsi alla capacità del popolo: strategie, metodi e impatto delle missioni nel Regno di Napoli, 1600-1800. Mélanges de l'École française de Rome - Italie et Méditerranée, 1997, no. 109, pp. 689-722 (in Italian).

39. Gombrich E. Arte e illusione. Studio della psicologia della rappresentazione pittorica. Turin, Einaudi Publ., 1962. 530 p. (in Italian).

40. Gordeeva N. La pittura russa sacra dal XV al XVII secolo della collezione Andrej Rublëv. Ragazzi F. (ed.). Icone russe del Museo Andrej Rublëv di Mosca. Genoa, Sagep Publ., 1989, pp. 19-21 (in Italian). 
41. Grabar I. A Catalogue of Russian Icons Received from the American Russian Institute for Exhibition. Worcester, Worcester Art Museum Publ., 1931. 72 p. and 113 pls.

42. Grasman E. On Closer Inspection - The Interrogation of Paolo Veronese. Artibus et Historiae, 2009, pp. 125-134.

43. Gusakova V. O. Slovar russkogo religioznogo iskusstva. Terminologia i ikonografia (Dictionary of Russian Religious Art: Terminology and Iconography). St. Peterburg, Aurora Publ., 2006. 280 p. (in Russian).

44. Hamilton G. H. The Art and Architecture of Russia. Harmondsworth, Penguin Books Publ., 1987. 482 p.

45. Icônes grecques et russes. Paris, Galerie Nikolenko Publ., 1977. 120 p. (in French).

46. Joannides P. Masaccio and Masolino. A Complete Catalogue. London, Phaidon Press Publ., 1993. 488 p.

47. Jones R.; Penny N. Raphael. New Haven; London, Yale University Press Publ., 1983. 256 p.

48. Kirschbaum G.; Braunfels W. Lexikon der Christlichen Ikonographie. Rome; Freiburg; Basel; Vienna, Herder Publ., 1968-1976. 8 vols. (in German).

49. Kitzinger E. I mosaici di Monreale. Palermo, Flaccovio Publ., 1991. 132 p. + 102 pls (in Italian).

50. Kłosinska I. Icônes de Pologne. Paris, Editions du cerf Publ., 1987. 165 p. (in French).

51. Komashko N. Central Andrey Rublev Museum of Ancient Russian Culture and Art, Moscow, Central Andrey Rublev Museum of Ancient Russian Culture and Art Publ., 2017. 36 p.

52. Kominis A. D. Patmos. Treasures of the Monastery. Athens, Ekdotikè Athenon Publ., 1988. 384 p.

53. Lazarev V. N. Moscow School of Icon Painting. Moscow, Iskusstvo Publ., 1971. 236 p.

54. Lazarev V. N. Novgorodian Icon Painting. Moscow, Iskusstvo Publ., 1976. 204 p.

55. Lazarev V. N. L'arte russa delle icone. Milan, Jaca Book Publ., 2008. 403 p. (in Italian).

56. Lazovic M. Icônes d'une collection privée. Genève, Musée d’Art et Histoire Publ., 1974. 118 p. (in French).

57. Lee R. W. Ut pictura poesis - la teoria umanistica della pittura. Florence, Sansoni Publ., 1974. 135 p. (in Italian).

58. Loginova A. S.; Zacharcuk A. Antiche icone dai Musei Sovietici - La pittura in Russia e in Ucraina dal XV al XVIII secolo. Florence, Electa Publ., 1984. 104 p. (in Italian).

59. Manfrin A. Pittura e Trinità, Prima parte - Antichità e Medioevo. Available at: www.parrocchiaporporano..it/pittura_trinità..html (accessed 25 January 2019) (in Italian).

60. Marc Chagall. Il messaggio biblico. Milan, Skira Publ., 1998. 85 p. (in Italian).

61. Mayer F. Marc Chagall. La vita e l'opera. Milano, Il Saggiatore, 1962. 776 p. (in Italian).

62. McCorquodale C. Bronzino. London, Jupiter Books Publ., 1981. 174 p.

63. Menz C. (ed.). Lumières de l'Orient chrétien. Icônes de la collection Abou Adal. Beiruth, Art et Patrimoine Publ., 1997. 319 p. (in French).

64. Molanus (= Vermeulen) J. De picturis et imaginibus sacris liber unus. Leuven, H. Welleum Publ., 1570. 230 p. (in Latin).

65. Monti R. Andrea del Sarto. Milano, Edizioni di Comunità Publ., 1981. 182 p. (in Italian).

66. Mutafov E. et al. Khristiankoe iskusstvo XIII-XIX vekov iz Museev Bolgarii (Christian Art of the $13^{\text {th }}$ $19^{\text {th }}$ Centuries from Museums of Bulgaria). Moscow, State Tretyakov Gallery Publ., 2018. 144 p. (in Russian).

67. Nechaeva T.; Popov G. et al. Severnye ekspeditsii muzeia imeni Andreia Rublieva 1963-1971 godi (Northern Expeditions of Andrey Rublev Museum 1963-1971). Moscow, Central Andrey Rublev Museum of Ancient Russian Culture and Art Publ., 2018. 128 p. (in Russian).

68. Nepi Scirè G. (ed.). Giambattista Tiepolo 1696-1996. Milan, Sira Publ., 1996. 398 p. (in Italian).

69. Nersesian L.; Suchoverkov D. Andrei Rublev - Sviataia Troitsa - Pokhvala prepodobnomu Sergiu (Andrei Rublev - Holy Trinity - Praise to St. Sergius). Moscow, State Tretyakov Gallery Publ., 2017. 67 p. (in Russian).

70. Ouspensky L.; Lossky V. The Meaning of Icons. New York, St. Vladimir’s Seminary Press Publ., 1989. 222 p.

71. Ostrowski D. The Moscow Councils of 1447 to 1589 and the Conciliar Period in Russian Orthodox Church History. Lupinin N.; Ostrowski D.; Spock J. B. (eds.). The Tapestry of Russian Christianity: Studies in History and Culture. Columbus Ohio, Resource Center for Medieval Slavic Studies, The Ohio State University Publ., 2016, pp. 121-155.

72. Paleotti G. Discorso intorno alle immagini sacre e profane (1582). Barocchi P. (ed.). Trattati d'arte del Cinquecento, vol. 2. Bari, Laterza Publ., 1960-1962, pp. 117-509 (in Italian).

73. Pallucchini R. I Vivarini (Antonio, Bartolomeo, Alvise). Venezia, Neri Pozza Publ., s.d. 156 p. + 282 figs. (in Italian).

74. Pelikan J. Imago Dei - The Byzantine Apologia for Icons. New Haven; London; Washington DC, Yale University Press and the National Gallery of Art Publ., 1990. 193 p.

75. Perini G. Arte in Europa, 1550-1650 - Letà dei conflitti religiosi. Turin, Utet Publ., 2007. 310 p. (in Italian). 
76. Perini Folesani G. Le Annunciazioni di Ludovico in prospettiva - Riflessioni in margine al ricercare del Carracci maggiore. Studiolo, 2013, pp. 110-126 (in Italian).

77. Perini Folesani G. Effetti collaterali del Nicodemismo: i Carracci in bilico tra eterodossia ed ortodossia, tra arte e scienza. Frascarelli D. (ed.). L'altro Seicento. Arte a Roma tra eterodossia, libertinismo e scienza. Roma, L'Erma di Bretschneider Publ., 2016, pp. 197-206 (in Italian).

78. Pettazzoni R. The Pagan Origins of the Three-Heads Representation of the Christian Trinity. Journal of the Warburg and Courtauld Institutes, 1946, no. 9, pp. 135-151.

79. Pirovano C. (ed.). Icone russe collezione Banca Intesa, Catalogo ragionato. Milano, Mondadori Electa Publ., 2003. 3 vols. (in Italian).

80. Popov G. Twerer Ikonen 13. bis 17. Jahrhundert. St. Petersburg, Aurora Publ., 1993. 283 p. (in German).

81. Popov G. V. Andrei Rubliov. Moscow, Severnyi Palomnik Publ., 2007. 215 p. (in Russian and English).

82. Provoyeur P. Marc Chagall, Messaggio biblico. Milan, Jaca Book Publ., 1983. 259 p. (in Italian).

83. Provoyeur P. Musée National, Message Biblique, Marc Chagall (Nice). Paris, Réunion des Musées Nationaux Publ., s. d. 52 p. (in French).

84. Rainoldi F. Forme iconologiche della Trinità e loro implicazioni dottrinali, paper read at the symposium "Arte e fede - Raffigurazioni trinitarie in alta valle e in diocesi di Como", Bormio, August 4 $4^{\text {th }}, 2012$. Available at: www.adfontes.it (accessed 25 January 2019) (in Italian).

85. Rousseau D. L'icona splendore del tuo volto. Cinisello Balsamo, Edizioni Paoline Publ., 1990. 252 p. (in Italian).

86. Saenz A. S. J. El icono esplendor de lo sagrado. s.l., Ediciones Gladius Publ., 2004. 422 p. (in Spanish).

87. Samoilova T. E. Skazanie o grade Sviiazhske (The Legend of the Town of Sviyazhsk). Moscow, Tretyakov Gallery Publ., 2018. 255 p. (in Russian).

88. Sarachev T. St Basil's Cathedral - Cathedral of the Intercession, guide. Moscow, The State Historical Museum Publ., 2017. 33 p.

89. Schade G. (ed.). Kunst der Reformationszeit. Berlin, Elefanten Press Publ., 1983. 448 p. (in German).

90. Schapiro M. Per una semiotica del linguaggio visivo. Rome, Meltemi Publ., 2002. 264 p. (in Italian).

91. Scheller R. Exemplum. Model-Book Drawings and the Practice of Artistic Transmission in the Middle Ages (ca. 900 - ca. 1470). Amsterdam, Amsterdam University Press Publ., 1995. 434 p.

92. Schiller G. Ikonographie der christlichen Kunst, 7 vols. Güterloh, Güterloher Verlagshaus G Mohn Publ., 1965-1980 (in German).

93. Skrobucha H. Icons in Czechoslovakia. London; New York; Sydney; Toronto, Hamlin Publ., 1971. 154 p.

94. Skrobucha H. Ikonenmuseum Recklinghausen. Recklinghausen, Aurel Bongersverlag Publ., 1981. 208 p. (in German).

95. Schweinfurth Ph. Russian Icons, New York; Toronto, Iris Books and Oxford University Press Publ., 1953. 60 p.

96. Shvidkovsky D. O. Aristotele Fioravanti in Russia. Frommel S. (ed.). Crocevia e capitale della migrazione artistica: forestieri a Bologna e bolognesi nel mondo (secoli XV-XVI). Bologna, Bononia University Press Publ., 2010, pp. 243-256 (in Italian).

97. Abbé Sionnet. Sainte Bible expliquée et commentée, contenant le texte de la Vulgate, la traduction et la paraphrase du P. de Carriéres et un nouvaeu commentaire littéral, 2 vols. Paris, Bureau de la Bibliothèque Ecclésiastique Publ., 1837 (in French).

98. Spencer J. R. Andrea del Castagno and His Patrons. Durham and London, Due University Press Publ., 1991. $180 \mathrm{p}$.

99. Stuart J. Ikons. London, Faber \& Faber Publ., 1975. 176 p.

100. Talbot Rice D. \& T. Icons and Their Dating. A Comprehensive Study of Their Chronology and Provenance. London, Thames \& Hudson Publ., 1974. 192 p.

101. Tarasov O. Icon and Devotion - Sacred Spaces in Imperial Russia. London, Reaktion Books Publ., 2002. 435 p.

102. Thuillier J. Sebastien Bourdon 1616-1671, Catalogue critique et chronologique de l'oeuvre complet. Paris, Runion des Musées Nationaux Publ., 2000. 528 p. (in French)

103. Toesca P. La Cappella Palatina di Palermo - I mosaici. Rome, Edizioni Mediterranee Publ., 1955. 84 p. (in Italian).

104. Voloshinov A. V. The Old Testament Trinity of Andrey Rubliov: Geometry and Philosophy. Leonardo, vol. 32, 1999, pp. 103-112.

105. Weitzmann K. et al. The Icon. London, Bracken Books Publ., 1987. 416 p.

106. Zibawi M. Icone. Senso e storia. Milano, Jaca Book Publ., 2000. 288 p. (in Italian). 
Title. Borderline Iconographies: The Limits of Visual Communication in Conveying Christian Dogmas in Early Modern Europe

Author. Giovanna Perini Folesani - full professor (of History of Art Literature). DISTUM (Dipartimento di Studi Umanistici), University of Urbino “Carlo Bo", Palazzo Albani, Via Bramante, 17, 61029 Urbino, Italy. giovanna.perini@uniurb.it

Abstract. Notwithstanding Cardinal Gabriele Paleotti's theory that images, unlike languages, are universally understood (1582) - a belief that supported contemporary Jesuit missions in Asia, Africa and the Americas - , experience soon proved the contrary. Subsequently some basic cognitive problems have been investigated (such as native Americans' and Asians' inability to understand chiaroscuro, which, together with perspective is the foundation of the Western notion of mimetic art). Some cultural problems have also been investigated, such as the Chinese revulsion for the image of the crucified Christ and the scandalous regularsize feet of female saints.

Less attention has been paid to the different meanings that the same Christian iconographies may have according to different Christian confessions. Thus the main difference between Andrei Rublev's Old Testament Trinity (Tretyakov Gallery, Moscow) and Ludovico Carracci's Abraham and the Three Angels (Bologna National Gallery) is not about style, but about meaning, despite the fact that both pictures represent the same episode from the Genesis (ch. XVIII, lines 1-8) and that the latter's invention is partly based on the former's. In this case differences depend on the East/West division, following the Church schism of 1054 - which engendered growing differences in theological statements, liturgy and iconographies. Even within the West, however, theology, liturgy and religious iconography are dealt with very differently, depending on the North/ South division created by the Protestant schism started in 1517.

The paper addresses the iconographical issues created by these religious divisions, focusing especially on the representations of the Old and the New Testament Trinity and of God the Father in Eastern and Western Europe, as well as on Protestant aniconism. It also shows how, despite divisions, East and West, North and South have mutually influenced each other's religious art, in terms of iconography and occasionally of style.

Keywords: Christian iconography, Cranach's Dogmenbilder, Inquisition, Nicodemism, Ludovico Carracci, Gabriele Paleotti

Название статьи. Пограничная иконография: пределы визуальной коммуникации в трансляции христианских догматов в европейском искусстве раннего Нового времени

Сведения об авторе. Перини Фолезани, Джованна - профессор. Урбинский университет имени Карло Бо, Палаццо Албани, Виа Браманте, 17, Урбино, Италия, 61029. giovanna.perini@uniurb.it

Аннотация. Несмотря на теорию кардинала Габриэле Палеотти, что изображения в отличие от языков понимаются всеми одинаково (1582), - а именно на этом постулате была основана миссия иезуитов в Азии, Африке и обеих Америках - практика показывает обратное. На сегодняшний день существуют исследования по некоторым базовым когнитивным проблемам (например, неспособность американских и азиатских туземцев воспринимать светотень, лежащую в основе европейского реалистического художественного метода). Также изучались частные культурные проблемы, например отторжение китайцами образа распятого Христа или непривычного им размера стоп ног в изображениях святых женщин.

Меньше внимания уделялось тому, что одна и та же иконография в различных христианских конфессиях может приобретать различный смысл. Таким образом, основное отличие «Троицы ветхозаветной» Андрея Рублёва (ГТГ, Москва) и «Авраама и трёх ангелов» Лодовико Карраччи (Болонья, Национальная галерея) не в стиле, а в значении, несмотря на то что оба произведения изображают один и тот же эпизод из Книги Бытия $(18,1-8)$ и композиция последнего отчасти построена на основе первого. В данном случае различия объясняются разделением Церквей в 1054 г., породившим все время усиливавшиеся разногласия в богословии, литургии и иконографии. Даже на Западе богословие, литургия и религиозная иконография разделились в связи с возникновением протестантизма в 1517 г.

Данная статья посвящена иконографическим особенностям, обусловленным этими религиозными отличиями, главным образом на примерах изображения ветхозаветной и новозаветной Троицы и Бога Отца в восточно- и западнохристианской иконографии, а также протестантскому отрицанию традиции иконного изображения. Кроме того, мы стремимся показать, что, несмотря на разделение, Восток и Запад, Север и Юг взаимно влияли друг на друга в области религиозной иконографии, а в некоторых случаях и стиля.

Ключевые слова: христианская иконография, догматические картины Кранаха, инквизиция, никодемизм, Лодовико Карраччи, Габриэле Палеотти 